\title{
ON THE ABSORPTION OF AMMONIA FROM THE ATMOSPHERE.
}

\author{
Bx A. D. HALL, M.A., F.R.S., AND N. H. J. MHUER, Ph.D. \\ The Rothamsted Experimental Station.
}

THRovGHOUT the whole history of agricultural chemistry attention has been fixed upon the ammonia in the atmosphere as a possible source of the nitrogen of vegetation, and without reviewing the early controversy that centred round Liebig, we may agree that the dispute was largely due to the exaggerated opinions then prevailing as to the amount of ammonia in the atmosphere. The most trustworthy determinations are the long series that have been carried out by Lévy ${ }^{1}$ at Montsouris, and they agree with otber determinations by $\dot{\nabla}$ ille $^{2}$, Schloesing ${ }^{z}$ and Müntz and Aubin', showing only from 01 to 02 of nitrogen as ammonia per million of air even in Paris, with a still smaller proportion in the air of the country.

This small proportion of ammonia may reach the soil in two ways:

(1) It is dissolved out by the rain.

(2) It may be absorbed directly by the soil.

The amount of ammonia brought down by the rain has already been fully discussed by one of us $^{5}$. The total amount brought down per acre per annum appears to be tolerably constant for ordinary country air despite variations in the rainfall, but it rises considerably in the neighbourhood of towns. Observations as yet unpublished indicate that a much smaller total amount of ammonia is brought down by

1 A. Léry, Annuaire de l'Observatoire de Montsouris, 1901.

2 G. Ville, Recherches Experimentales sur la Végétation, Paris, 1868.

3. Tchloesing, Contributions à l'étude de la Chimie agricole, Paris, 1888.

- Müntz and Aubin, Rapport sur des Trvcherches de Chimie appliqué à la science agricule et à la méteorologie executées au Pic du Midi, Pariß, 1883.

${ }^{s}$ N. H. J. Miller, Journ. Agric. Sci. 1905, x. 280. 
the rain falling on the extreme western seaboard of Scotland, where the air may be supposed to have received a minimum of contamination from habitations or contact with the land surface.

There remains the question of whether the soil takes in ammonia by direct absorption from the atmosphere. Of course it is well known that the soil is a very effective absorbent of ammonia, and it might be assumed to be capable of taking away from the air even the very small trace which can be determined therein. It must, however, be borne in mind that the soil itself is a possible source of ammonia. The soil organisms are always producing ammonium compounds, so that a small and fairly constant percentage of ammonium salts is to be found in the soil, representing the transition stage between organic compounds of nitrogen and nitrates. As most soils also contain some calcium carbonate, which by interaction with the ammonium salts would give rise to ammonium carbonate, and ammonium carbonate possesses an appreciable tension of dissociation at soil temperatures, the soil itself must be capable of giving off ammonia to the atmosphere above it. Berthelot ${ }^{1}$ enclosed soils with dishes of acid under bell jars and found an appreciable transfer of ammonia from the soil to the acid, and Schneidewind ${ }^{2}$ found in the laboratory that soil recently manured with ammonium salts will yield ammonia to a current of air; as will be shown later in the paper such losses can become appreciable under field conditions. It will be safest to assume that the soil possesses a certain ammonia tension, more or less in equilibrium with the air above it, but there are no data upon wbich to base a conclusion as to whether the gradient is normally from the air to the soil or vice versa. To a certain extent the question of the source of the ammoniu in the atmosphere is involved in this question. Boussingaults was of the opinion that the sea-water contains so much free ammonia that the oceans are the great source of atmospheric ammonia and are in equilibrium with the atmosphere so as to maintain the stock at a fairly constant proportion. From this point of view the sea is the source, and the land both by direct absorption and through the intermediate agency of the rain falling upon the land, is reducing the amount in the atmosphere. On the other hand, many terrestrial sources of ammonia can be specified; the smoke arising from coal fires shows its effect in the increased amount of ammonia in the rain of towns, and all decaying animal and vegetable matter must be contributing some ammonia to

1 M. P. E. Berthelot, Chimie végetale et agricole, 1. Paris, 1899.

2 W. Schneidewind, et al., Landro. Jahrb. 1910, 8๑. Erg.-bd. II. 221.

3 Boussingault, Agronomie, Paris, 1860-84, ㅍ. 208. 
the air. Volcanic emanations afford another terrestrial source of ammonia, though the numbers of active volcanoes in relation to the total amount of the atmosphere would seem to render such contributions inappreciable.

The question of whether the soil does gain any ammonia from the atmosphere by direct absorption is one of considerable importance in any attempts to construct a balance sheet for the nitrogen received by, and removed from, an experimental plot over any length of time, and the following investigations were initiated with the view of obtaining further light upon the problem. In the first place attempts were made to ascertain if ordinary arable soil either gave up or absorbed any appreciable amount of ammonia when a current of air from the open and therefore containing some ammonia was passed over it. A tube of about $6 \mathrm{ft}$. long and one inch in diameter was filled with arable soil in a moist condition, and connected with a Reiset absorption column, a meter, and a water pump. Another Reiset column and a second meter was linked up to the same pump and arranged so as to draw approximately the same quantities of air through both. The apparatus was placed in the open a few yards from the laboratory, connexion to the water pump being made by a long metal tube. The result proved entirely negative, no difference could be detected in the amount of ammonia absorbed; although the pump was allowed to run for many days until from one to two thousand litres of air were drawn over in each experiment. The experiments, however, were conducted on much too small a scale to admit of any conclusions, and as no more efficient pump was available the method was abandoned in favour of the one to be described. Other investigators have attempted to measure the maximum amount of ammonia which might be absorbed from the atmosphere by exposing dishes of acid for a considerable length of time, and then neutralising and distilling over the ammonia for determination. It was decided to repeat these determinations, exposing the dishes under such varying conditions as would give some indication of the source of ammonia. Four pairs of dishes of glazed earthenware 26.5 centimetres in diameter and having a surface of 550 square centimetres were exposed in pairs, one dish at about 5 centimetres from the ground, the upper one at about 115 centimetres. The dishes were about $3 \mathrm{~cm}$. deep and were protected from rain by large sheets of glass fixed at a slight angle above them. One pair of disbes was exposed on the lawn in front of the laboratory; the situation is open, but there are a few house chimneys at no great distance. Two pairs were exposed at different parts of the 
Broadbalk wheat field in a very open situation, especially to the west. Another pair were exposed on the Park grass plots where they are even more remote from houses, but are somewhat sheltered by belts of trees. In each dish 50 c.c. of normal sulphuric acid and 200 c.c. of distilled water were placed, the materials being previously freed from ammonia As this solution was found to dry up too readily, in the latter experiments for which the figures are given 70 c.c. of glycerol replaced an equal volume of water. The dishes were exposed for a month in each case, whereupon the solutions were washed out and replaced prior to the determination of the absorbed ammonia. The early experiments were carried out by the late Mr F. S. Marr, as were the attempts described above to ascertain the effect of soil upon the ammonia content of the air, but the figures contained in the tables were all obtained since his departure from Rothamsted laboratory.

In a preliminary experiment in which dilute acid alone was placed in the dishes, comparatively high results were obtained, about one milligramme of nitrogen being absorbed per dish per month, which would be equivalent to about $2 \mathrm{ll}$. per acre per month. It was found, however, impossible to keep the solutions at all clean; not only was there a considerable influx of dust, but especially in the lower dishes a number of small tlies and other insects were caught by the liquid and very probably furnished some ammonia by hydrolysis of their nitrogen compounds. Accordingly in the later experiments each dish was covered by a sheet of brass wire gauze of 100 meshes to the inch, and though this did not entirely exclude dust it kept out the insects which vitiated the early experiments.

Table I. shows the monthly results obtained for the two years from November 1908 to October 1910, expressed as milligrammes of nitrogen absorbed per dish. As the figures obtained for the two years are consistent and show no large variation from month to month it did not seem necessary to carry the work any further. In the first place it will be seen, with certain exceptions to be discussed later, that the upper dish gives almost always a higher result than the lower one. Very markedly is this the case with the dishes exposed near the laboratory, but the difference is comparatively small with the dishes exposed on the grass land. The greater absorption by the upper dish can be set down to the more frequent renewal of the air above the dish; it seems more probable that the atmosphere is alike in the two levels, and that the observed differences are brought about by the greater play of air upon the upper dishes. 
60 Absorption of Ammonia from the Atmosphere

TABLE I.

Ammonia Absorption.

(Norember 1908 to October 1910.)

\begin{tabular}{|c|c|c|c|c|c|c|c|c|}
\hline & \multicolumn{8}{|c|}{ Nitrogen per dish (mg.) } \\
\hline \multirow[t]{3}{*}{. } & \multicolumn{4}{|c|}{ Broadbalk } & \multicolumn{2}{|c|}{ Park } & \multicolumn{2}{|c|}{ Laborator $\dot{y}$} \\
\hline & \multicolumn{2}{|c|}{ Plot 7} & \multicolumn{2}{|c|}{ Plot 12} & \multirow{2}{*}{ Upper } & \multirow{2}{*}{ Lower } & \multirow{2}{*}{ Upper } & \multirow{2}{*}{ Lower } \\
\hline & Upper & Lower & Upper & Lower & & & & \\
\hline 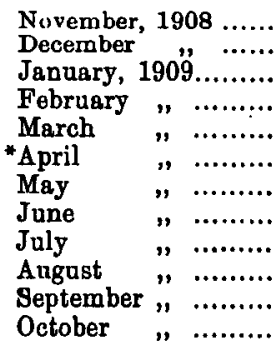 & $\begin{array}{l}\cdot 425 \\
\cdot 425 \\
\cdot 325 \\
\cdot 313 \\
\cdot 306 \\
2 \cdot 063 \\
\cdot 640 \\
\cdot 344 \\
\cdot 400 \\
\cdot 550 \\
\cdot 550 \\
\cdot 525\end{array}$ & $\begin{array}{r}\cdot 475 \\
\cdot 288 \\
\cdot 333 \\
\cdot 244 \\
\cdot 300 \\
4 \cdot 000 \\
\cdot 525 \\
\cdot 350 \\
\cdot 281 \\
\cdot 400 \\
\cdot 450 \\
\cdot 350\end{array}$ & $\begin{array}{r}\cdot 400 \\
.350 \\
\cdot 313 \\
.350 \\
.319 \\
1 \cdot 531 \\
1 \cdot 042 \\
.328 \\
\cdot 460 \\
.625 \\
.350 \\
\cdot 350\end{array}$ & $\begin{array}{r}-350 \\
-263 \\
.263 \\
.275 \\
\cdot 250 \\
\mathbf{3} \cdot 500 \\
\cdot 656 \\
.325 \\
.238 \\
\cdot 375 \\
\cdot 375 \\
\cdot 250\end{array}$ & $\begin{array}{l}\cdot 475 \\
\cdot 333 \\
\cdot 313 \\
\cdot 256 \\
\cdot 269 \\
\cdot 325 \\
\cdot 500 \\
\cdot 375 \\
\cdot 350 \\
\cdot 400 \\
\cdot 400 \\
\cdot 350\end{array}$ & $\begin{array}{l}\cdot 200 \\
\cdot 263 \\
\cdot 175 \\
\cdot 294 \\
\cdot 183 \\
\cdot 288 \\
\cdot 438 \\
\cdot 425 \\
\cdot 300 \\
\cdot 425 \\
\cdot 400 \\
\cdot 325\end{array}$ & $\begin{array}{r}1 \cdot 580 \\
.650 \\
.450 \\
.450 \\
.413 \\
.413 \\
.600 \\
.575 \\
.625 \\
.650 \\
.800 \\
1 \cdot 313\end{array}$ & $\begin{array}{l}\cdot 450 \\
\cdot 400 \\
\cdot 333 \\
\cdot 282 \\
\cdot 325 \\
\cdot 338 \\
\cdot 425 \\
\cdot 400 \\
\cdot 413 \\
\cdot 425 \\
\cdot 525 \\
\cdot 550\end{array}$ \\
\hline Nov. 1908-Oet. 1909 & $6 \cdot 866$ & $7 \cdot 996$ & $6 \cdot 418$ & $7 \cdot 120$ & $4 \cdot 346$ & $3 \cdot 716$ & $8 \cdot 519$ & $4 \cdot 866$ \\
\hline Average.......... & $\cdot 572$ & $\cdot 666$ & $\cdot 535$ & $\cdot 523$ & $\cdot 862$ & $\cdot 309$ & $\cdot 709$ & $\cdot 405$ \\
\hline 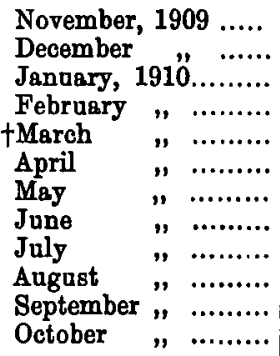 & $\begin{array}{l}\cdot 500 \\
\cdot 700 \\
\cdot 450 \\
\cdot 475 \\
1 \cdot 200 \\
\cdot 780 \\
\cdot 494 \\
\cdot 400 \\
\cdot 475 \\
\cdot 500 \\
\cdot 550 \\
\cdot 488\end{array}$ & $\begin{array}{c}\cdot 367 \\
\cdot 575 \\
\cdot 425 \\
(\cdot 575) \\
5 \cdot 125 \\
\cdot 850 \\
\cdot 481 \\
\cdot 325 \\
\cdot 500 \\
\cdot .396 \\
\cdot 504 \\
\cdot 775\end{array}$ & $\begin{array}{r}\cdot 525 \\
\cdot 525 \\
\cdot 450 \\
\cdot 425 \\
1 \cdot 625 \\
\cdot 800 \\
\cdot 735 \\
\cdot 288 \\
\cdot 475 \\
\cdot 563 \\
\cdot 587 \\
\cdot 750\end{array}$ & $\begin{array}{c}\cdot 288 \\
\cdot 333 \\
\cdot 375 \\
(\cdot 688) \\
5 \cdot 375 \\
2 \cdot 000 \\
\cdot 525 \\
\cdot 338 \\
\cdot 450 \\
\cdot 375 \\
\cdot 400 \\
\cdot 450\end{array}$ & $\begin{array}{l}\cdot 545 \\
\cdot 475 \\
\cdot 425 \\
\cdot 525 \\
\cdot 475 \\
\cdot 438 \\
\cdot 425 \\
\cdot 288 \\
\cdot 375 \\
\cdot 459 \\
\cdot 441 \\
\cdot 375\end{array}$ & $\begin{array}{l}\cdot 375 \\
\cdot 317 \\
\cdot 350 \\
\cdot 450 \\
\cdot 333 \\
\cdot 338 \\
\cdot 475 \\
\cdot 650 \\
\cdot 475 \\
\cdot 490 \\
\cdot 373 \\
\cdot 213\end{array}$ & $\begin{array}{r}.625 \\
1.833 \\
1.313 \\
.950 \\
.500 \\
.475 \\
.450 \\
.250 \\
.525 \\
.625 \\
1.175 \\
1.000\end{array}$ & $\begin{array}{l}\cdot 450 \\
\cdot 433 \\
\cdot 400 \\
\cdot 525 \\
\cdot 325 \\
\cdot 350 \\
\cdot 250 \\
\cdot 225 \\
\cdot 950 \\
\cdot 646 \\
\cdot 529 \\
\cdot 525\end{array}$ \\
\hline Nov. $1909-$ Oct. 1910 & $7 \cdot 012$ & $10 \cdot 898$ & $7 \cdot 748$ & $11 \cdot 597$ & $5 \cdot 246$ & $4 \cdot 839$ & $9 \cdot 721$ & $5.608^{\circ}$ \\
\hline Average........... & $\cdot 584$ & $\cdot 908$ & $\cdot 646$ & .966 & $\cdot 437$ & $\cdot 403$ & $\cdot 810$ & -467 \\
\hline
\end{tabular}

* Manures applied April 7, 1909. † Manures applied March 16, 1910.

It would be noticed that in certain months of the year the amount absorbed by the dishes above the arable Broadbalk field is much above 
the normal, rising from an average of little over 5 to as much as 5 milligrammes of ammonia per dish. On this occasion also the lower dishes give the higher results. This sudden jump in the amount of ammonia in the atmosphere only occurred over the Broadbalk field, and occurred in April 1909 and in March 1910, months which coincided with the application of ammonium sulphate and chloride as manures to the soil of these fields. The highest results are obtained in the months of application (April 1909 and March 1910) but the quantity absorbed is still much above normal in the following month, especially in 1910, in which year the manure was put on as late in March as the 16th, whereas in the previous year the manuring had been on the 7th of the month. Thus the application of an ammoniacal manure affects the air for more than three but less than seven weeks after its application. As the dishes were removed during the actual sowing of the manures and only replaced in their stands a day or two afterwards, the sudden rise in the amount of ammonia absorbed cannot be due to the intrusion of any manure dust, but must have been brought about by an actual evolution of ammonia from the soil, and this conclusion is strengthened by the fact that the lower dishes nearest to the soil absorbed the most ammonia. The amount absorbed from the two disbes during the month of application and the one following, is in itself comparatively small and would not amount to a pound of nitrogen per acre, whereas about 83 pounds per acre were supplied in the fertiliser.

Small as this amount actually absorbed is, it can only represent a fraction of the total ammonia given up by the soil to the air over this manured field, so that we may fairly conclude that the loss of ammonia as such is by no means negligible when the land is manured with ammonium salts. The Rothamsted soil is only slightly calcareous, containing in this field from two to three per cent. of calcium carbonate in the surface nine inches of soil; as it is also a heavy soil retentive of moisture, the losses would tend to be below the normal of most soils.

Turning now to a comparison of the three situations, Table II shows the total absorption for ten months of each year, excluding April and May 1909 and March and April 1910, the two months following the applications of the manures on Broadbalk.

It would be seen that the arable land gives slightly higher results than the Park grass land, and that both are distinctly below the results on the laboratory lawn. These results are not consistent with an absorption of the ammonia by the soil, because one must suppose that the bare arable soil would have a more powerful absorbing effect upon 
the air above it than the grass land. Moreover, there is no falling off in the absorption of nitrogen above the arable land in the months of September and October, months of the year during which this field (permanent wheat) is being cultivated, when it would expose a maximum of fresh absorbing surface. The small difference between the grass and arable land is best explained by the difference in exposure, which results in a much more vigorous air circulation above the arable field; and this conclusion is strengthened by the fact that the greater absorption above the arable land is much more marked for the upper dishes than for the lower.

\section{Table II.}

Total Nitrogen as Ammonia absorbed per dish in 10 months (mg.).

\begin{tabular}{|c|c|c|c|c|c|c|c|c|}
\hline & \multicolumn{2}{|c|}{$\begin{array}{l}\text { Broadbalk, } \\
\text { Plot } 7\end{array}$} & \multicolumn{2}{|c|}{$\begin{array}{l}\text { Broadbalk, } \\
\text { Plot } 12\end{array}$} & \multicolumn{2}{|c|}{ Purk } & \multicolumn{2}{|c|}{ Laboratory } \\
\hline & Upper & Lower & Upper & Lower & Opper & Lower & Upper & Lower \\
\hline $1908-1909 \ldots \ldots$ & $4 \cdot 163$ & $3 \cdot 471$ & 3.845 & $2 \cdot 964$ & $3 \cdot 521$ & $2 \cdot 990$ & $7 \cdot 506$ & $4 \cdot 103$ \\
\hline $1909-1910 \ldots$ & $5 \cdot 032$ & 4.923 & $5 \cdot 323$ & $4 \cdot 222$ & $4 \cdot 333$ & $4 \cdot 168$ & $8 \cdot 746$ & 4.933 \\
\hline
\end{tabular}

The dishes on the laboratory lawn shew by far the highest figures, due doubtless to the greater contamination of the air by the chimneys that are near. The difference between the upper and lower dishes is also most pronounced on the laboratory lawn, which would again agree with the conclusion that the source of ammonia is aerial, i.e. that in the main it comes from the chimneys.

It may be noticed that the amount of absorption by the upper dish on the laboratory lawn reached comparatively high fgures on certain occasions, being over the milligramme in November 1908, October and December 1909, and January, September and October 1910. It has not been found possible to correlate these variations with the prevailing weather, but it should be noted that, with the exception of September 1910 , they occur in the winter half of the year when the consumption of coal would be at a maximum. If the comparison between winter and summer months is made for all the plots, again excluding the two months in each year, Table III., it is only the laboratory station which shows any increase of ammonia during the winter as compared with the suminer months. 


\section{TABLE III.}

Average Absorption of Ammonia per month, Winter and Summer (excluding April, May, 1909, and March, April, 1910).

(mg. per dish.)

\begin{tabular}{|c|c|c|c|c|c|c|c|c|}
\hline & \multicolumn{2}{|c|}{$\begin{array}{l}\text { Broadbalk, } \\
\text { Plot } 7\end{array}$} & \multicolumn{2}{|c|}{$\begin{array}{l}\text { Broadbalk, } \\
\text { Plot } 12\end{array}$} & \multicolumn{2}{|c|}{ Park } & \multicolumn{2}{|c|}{ Laboratory } \\
\hline & Upper & Lower & Upper & Lower & Upper & Lower & Upper & Lower \\
\hline $\left.\begin{array}{c}\text { Winter months, } \\
\text { October-March }\end{array}\right\}$ & $\cdot 448$ & $\cdot 428$ & $\cdot 432$ & $\cdot 344$ & $: 39 \overline{5}$ & $\cdot 286$ & $\cdot 888$ & -425 \\
\hline $\left.\begin{array}{c}\text { Summer months, } \\
\text { April-September }\end{array}\right\}$ & $\cdot 474$ & $\cdot 410$ & $\cdot 490$ & $\cdot 378$ & $\cdot 390$ & $\cdot 446$ & 631 & $\cdot 485$ \\
\hline
\end{tabular}

As the rain also derives its ammonia from the atmosphere one might expect there would be some connexion between the richness of the air in ammonia as determined by this absorption method and the amount of ammonia brought down by the rain during the same period. In Table IV a comparison is made between the average monthly absorption in the three dishes situated on. Broadbalk field and the Park, and the quantity of ammonia in the rain which is collected in a third field still in the open, though rather nearer to the village of Harpenden than either Broadbalk or the Park.

The concentration of the rain in ammonia depends to some extent upon the magnitude of the rainfall, being higher in months of low rainfall. In consequence the figures are given for both parts of ammonia per million of rain, and total ammonia per acre brought down each month. It will be seen that there is no connexion between the two sets of figures, either inverse or direct.

The results set out in Table I. for the nitrogen absorbed per dish may now be recalculated as $\mathrm{lb}$. per acre and kilos per hectare, Tables V. and VI.

The surprising feature about these results is the small magnitude of the annual absorption per acre. The highest average result for the two years is only 1.533 pounds per acre of nitrogen (1.718 k. per h.) absorbed for the lower dish over the Broadbalk field, the upper dish near the laboratory giving slightly lower figures. 
TABLE IV.

Ammonia Absorption and Ammonia in Rain.

(November 1908 to October 1910.)

\begin{tabular}{|c|c|c|c|c|c|}
\hline & \multicolumn{2}{|c|}{$\begin{array}{l}\text { Nitrogen absorbed } \\
\text { per acre }\end{array}$} & \multicolumn{2}{|c|}{ Nitrogen in Rain } & \multirow{2}{*}{ Rainfall } \\
\hline & Upper * & Lower* & Per million & Per acre & \\
\hline $\begin{array}{l}\text { November, } 1908 \\
\text { December }\end{array}$ & $\begin{array}{l}\text { lbs. } \\
.070 \\
.060 \\
.052 \\
.050 \\
.049 \\
.212 \\
.118 \\
.057 \\
.066 \\
.085 \\
.070 \\
.066\end{array}$ & $\begin{array}{l}\text { lbs. } \\
.055 \\
.044 \\
.042 \\
.044 \\
.039 \\
.422 \\
.087 \\
.059 \\
.045 \\
.065 \\
.066 \\
.050\end{array}$ & $\begin{array}{l} \\
\cdot 800 \\
\cdot 500 \\
\cdot 781 \\
1 \cdot 281 \\
\cdot 470 \\
\cdot 450 \\
\cdot 766 \\
\cdot 400 \\
.425 \\
\cdot 719 \\
.917 \\
\cdot 263\end{array}$ & $\begin{array}{l}\text { lbs. } \\
\cdot 149 \\
\cdot 250 \\
\cdot 173 \\
\cdot 125 \\
-398 \\
\cdot 186 \\
\cdot 228 \\
.370 \\
\cdot 298 \\
\cdot 446 \\
.403 \\
\cdot 309\end{array}$ & $\begin{array}{l}\text { inches } \\
0 \cdot 821 \\
2 \cdot 065 \\
0 \cdot 978 \\
0 \cdot 430 \\
3 \cdot 742 \\
1 \cdot 822 \\
1 \cdot 315 \\
4 \cdot 097 \\
3 \cdot 097 \\
2 \cdot 739 \\
1 \cdot 943 \\
5 \cdot 187\end{array}$ \\
\hline Nov. 1908 -Oct. $1909 \ldots$ & .955 & $1 \cdot 018$ & - & $3 \cdot 335$ & $28 \cdot 236$ \\
\hline 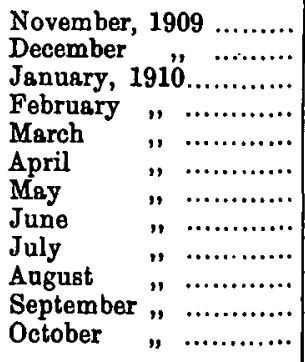 & $\begin{array}{l}.084 \\
.092 \\
.072 \\
.077 \\
.178 \\
.109 \\
.089 \\
.053 \\
.072 \\
.082 \\
.085 \\
.087\end{array}$ & $\begin{array}{l}.056 \\
.066 \\
.062 \\
.093 \\
.586 \\
.172 \\
.081 \\
.070 \\
.077 \\
.068 \\
.070 \\
.078\end{array}$ & $\begin{array}{l}\cdot 550 \\
.250 \\
.350 \\
.225 \\
\cdot 300 \\
\cdot 625 \\
.450 \\
\cdot 475 \\
\cdot 425 \\
\cdot 400 \\
.525 \\
\cdot 475\end{array}$ & $\begin{array}{l}\cdot 165 \\
\cdot 193 \\
\cdot 173 \\
\cdot 192 \\
\cdot 084 \\
\cdot .224 \\
\cdot 220 \\
\cdot 302 \\
\cdot 192 \\
\cdot .906 \\
\cdot 106 \\
\cdot 804\end{array}$ & $\begin{array}{l}1 \cdot 245 \\
\mathbf{3} \cdot 416 \\
2 \cdot 183 \\
3 \cdot 780 \\
1 \cdot 235 \\
1 \cdot 581 \\
2 \cdot 164 \\
2 \cdot 806 \\
1 \cdot 996 \\
3 \cdot 379 \\
9 \cdot 889 \\
2 \cdot 830\end{array}$ \\
\hline Nov. 1909 -Oct. $1910 \ldots$ & $1 \cdot 080$ & $1 \cdot 479$ & - & $2 \cdot 451$ & $27 \cdot 504$ \\
\hline
\end{tabular}

* Mean of Broadbalk and Park.

Kellner', at Tokio, who exposed dishes of nearly the same size for two years, got an average absorption of 10.51 pounds per acre (11.78 k. per h.). Heinrich ${ }^{2}$ at Rostock by exposing dishes 10 centimetres in diameter for two years, obtained $25 \cdot 2$ pounds per acre or $30.6 \mathrm{k}$.

1 O. Kellner, \&c., Landw. Jahrb. 1886, xv.

2 R. Heinrich, Wollny's Forschungen, 1881, iv. 446. 


\section{TABLE V.}

- Ammonia Absorption.

(November 1908 to October 1910.)

\begin{tabular}{|c|c|c|c|c|c|c|c|c|}
\hline & \multicolumn{8}{|c|}{ Nitrogen per acre (lb.) } \\
\hline & \multicolumn{4}{|c|}{ Broadbalk } & \multicolumn{2}{|c|}{ Park } & \multicolumn{2}{|c|}{ Laboratory } \\
\hline & \multicolumn{2}{|c|}{ Plot 7} & \multicolumn{2}{|c|}{ Plot 12} & \multirow{2}{*}{ Upper } & \multirow{2}{*}{ Lower } & \multirow{2}{*}{ Upper } & \multirow{2}{*}{ Lower } \\
\hline & Upper & Lower & Upper & Lower & & & & \\
\hline 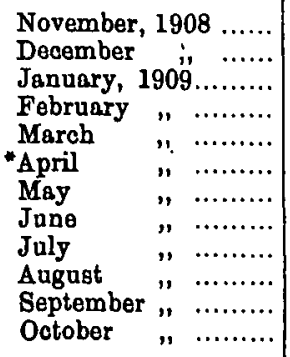 & $\begin{array}{l}\cdot 069 \\
.069 \\
.052 \\
.051 \\
.050 \\
.335 \\
\cdot 104 \\
.056 \\
\cdot 065 \\
.089 \\
.089 \\
.085\end{array}$ & $\begin{array}{l}.077 \\
.047 \\
.054 \\
.039 \\
.049 \\
.649 \\
.085 \\
.057 \\
.046 \\
.065 \\
.073 \\
.057\end{array}$ & $\begin{array}{l}\cdot 065 \\
.057 \\
.052 \\
.057 \\
\cdot 052 \\
.248 \\
.169 \\
.054 \\
.075 \\
\cdot .02 \\
.057 \\
.057\end{array}$ & $\begin{array}{l}.057 \\
.043 \\
.043 \\
.045 \\
.040 \\
.568 \\
\cdot 106 \\
.052 \\
.038 \\
.061 \\
.061 \\
.040\end{array}$ & $\begin{array}{l}.077 \\
.054 \\
.052 \\
.042 \\
.044 \\
.052 \\
.081 \\
.061 \\
.057 \\
.065 \\
.065 \\
.057\end{array}$ & $\begin{array}{l}.032 \\
.043 \\
.029 \\
.047 \\
.029 \\
.047 \\
.071 \\
.069 \\
.050 \\
.069 \\
.065 \\
.052\end{array}$ & $\begin{array}{l}\cdot 256 \\
\cdot 105 \\
\cdot 073 \\
\cdot 073 \\
\cdot 067 \\
\cdot 067 \\
\cdot 097 \\
\cdot 094 \\
\cdot 102 \\
\cdot 105 \\
\cdot 130 \\
\cdot 214\end{array}$ & $\begin{array}{l}.073 \\
.065 \\
.054 \\
.045 \\
.052 \\
.054 \\
.069 \\
.065 \\
.067 \\
.071 \\
.085 \\
.089\end{array}$ \\
\hline Nov. $1908-$ Oct. 1909 & $1 \cdot 114$ & $1 \cdot 298$ & $1 \cdot 045$ & $1 \cdot 154$ & $\cdot 707$ & $\cdot 603$ & $1 \cdot 383$ & $\cdot 789$ \\
\hline Average......... & .093 & $\cdot 108$ & .087 & .096 & 059 & .050 & $\cdot 115$ & $\cdot 066$ \\
\hline 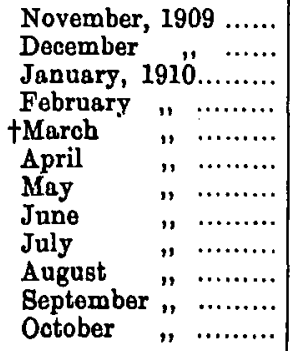 & $\begin{array}{l}\cdot 081 \\
\cdot 113 \\
\cdot 073 \\
.077 \\
\cdot 195 \\
\cdot 127 \\
.080 \\
.065 \\
.077 \\
.081 \\
.089 \\
.080\end{array}$ & $\begin{array}{l}\cdot 060 \\
0093 \\
\cdot 069 \\
\cdot 093 \\
\cdot 832 \\
\cdot 138 \\
\cdot 079 \\
\cdot 052 \\
\cdot 081 \\
\cdot 064 \\
.082 \\
\cdot 126\end{array}$ & $\begin{array}{r}\cdot 085 \\
\cdot 085 \\
\cdot 073 \\
\cdot 069 \\
\cdot 263 \\
\cdot 129 \\
\cdot 119 \\
\cdot 047 \\
\cdot 077 \\
\cdot 091 \\
.096 \\
\cdot 121\end{array}$ & $\begin{array}{l}\cdot 047 \\
\cdot 054 \\
\cdot 061 \\
\cdot 112 \\
\cdot 872 \\
\cdot 325 \\
\cdot 085 \\
\cdot 054 \\
\cdot 073 \\
\cdot 061 \\
\cdot 065 \\
\cdot 073\end{array}$ & $\begin{array}{l}\cdot 085 \\
.077 \\
\cdot 069 \\
\cdot 085 \\
\cdot 077 \\
\cdot 071 \\
.069 \\
\cdot 047 \\
\cdot 061 \\
\cdot 074 \\
\cdot 071 \\
\cdot 060\end{array}$ & $\begin{array}{l}-061 \\
\cdot 052 \\
\cdot 057 \\
\cdot 073 \\
\cdot 054 \\
.054 \\
\cdot 077 \\
\cdot 105 \\
\cdot 077 \\
\cdot 080 \\
.061 \\
\cdot 035\end{array}$ & $\begin{array}{l}\cdot 102 \\
\cdot 297 \\
\cdot 214 \\
\cdot 154 \\
\cdot 081 \\
\cdot 077 \\
\cdot 073 \\
\cdot 040 \\
\cdot 085 \\
\cdot 102 \\
\cdot 191 \\
\cdot 162\end{array}$ & $\begin{array}{l}\cdot 073 \\
\cdot 070 \\
\cdot 065 \\
\cdot 085 \\
\cdot 052 \\
\cdot 057 \\
\cdot 040 \\
\cdot 037 \\
\cdot 154 \\
\cdot 104 \\
\cdot 086 \\
\cdot 085\end{array}$ \\
\hline Nor. 1909 -Oct. 1910 & $1 \cdot 138$ & $1 \cdot 769$ & $1 \cdot 255$ & $1 \cdot 882$ & .846 & $\cdot 786$ & 1.578 & $\cdot 908$ \\
\hline Average.......... & .095 & $\cdot 147$ & $\cdot 105$ & $\cdot 157$ & .070 & .065 & $\cdot 131$ & $\cdot 076$ \\
\hline
\end{tabular}

- Manures applied April 7, $1909 . \quad$ † Manures applied March 16, 1910. Journ. of Agrio. Soi. IV 
per $h$. Bineau ${ }^{1}$ at Lyons also exposed dishes whose diameter is only approximately given; taking, however, the quoted figure of 6 centimetres his result would be $53.6 \mathrm{k}$. per $\mathrm{b}$. in Lyons and 14.7 at Caluire. This author stales that the Lyons figures were much affected by dust, and that there were many gnats at Caluire, but as soaking small gnats in his dilute acid for eight days gave him only half a milligramme of nitrogen, he concluded that they had not affected the result appreciably. It is, however, to the dust and living objects which find their way into the acid that we attribute the discrepancy between our own results and those of previous observers, and as it is impossible to exclude this source of error entirely no absolute value can be attached to the results. Moreover, the wire gauze screen placed over the dishes in our experiments may have a considerable effect upon the rate of absorption, by checking the rapidity with which the air is renewed above the dish. To ascertain the effect of the gauze covering two dishes, one covered with the gauze, the other uncovered, were exposed in the open field for three weeks in the winter, when it was expected that dust and insects would be at a minimum. The following figures show that the exposure of the uncovered dish was so much greater that six times as much water evaporated from it and four times as much ammonia was absorbed. Though the exposure was made in Junuary when the land was pretty wet a good deal of dust still found its way. in to the uncovered dish.

In a second trial the covered and uncovered dishes were exposed in a large unheated building, the doors of which were open from time to time. In this case the two dishes absorbed almost the same amount of ammonia though the evaporation was much greater from the uncovered dish.

\begin{tabular}{l|l|c|c}
\hline & & $\begin{array}{c}\text { Ammonis absorbed } \\
\text { mgm. N. }\end{array}$ & Evaporation, c.c. \\
\hline Open field-21 days winter & $\left\{\begin{array}{l}\text { Covered dish } \\
\text { Uncovered dish }\end{array}\right.$ & $\begin{array}{l}0.225 \\
1.000\end{array}$ & $\begin{array}{l}130 \\
790\end{array}$ \\
\hline In-doors-10 dajs winter & $\left\{\begin{array}{l}0.200 \\
0.212\end{array}\right.$ \\
\hline
\end{tabular}

These results indicate that the free play of air over the uncovered dishes bas increased the absorption, the figure obtained for the

1 A. Binesa, Études chiniques, sur les eaux pluviales et sur l'atmosphère de Lyon et de quelques points des environs, Lyon, 1854. 
TaBLE VI.

Ammonia Absorption.

(November 1908 to October 1910.)

\begin{tabular}{|c|c|c|c|c|c|c|c|c|}
\hline & \multicolumn{8}{|c|}{ Nitrogen per heotere (kilos) } \\
\hline & \multicolumn{4}{|c|}{ Broadbalk } & \multicolumn{2}{|c|}{ Park } & \multicolumn{2}{|c|}{ Laboratory } \\
\hline & \multicolumn{2}{|c|}{ Plot 7} & \multicolumn{2}{|c|}{ Plot 12} & \multirow{2}{*}{ Upper } & \multirow{2}{*}{ Lower } & \multirow{2}{*}{ Upper } & \multirow{2}{*}{ Lower } \\
\hline & Upper & Lower & Upper & Lower & & & & \\
\hline 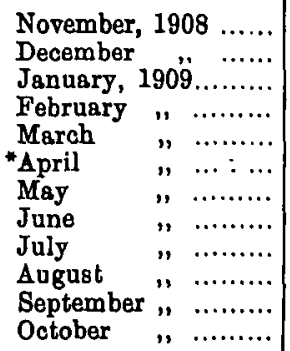 & $\begin{array}{l}.077 \\
.077 \\
.059 \\
.057 \\
.056 \\
.375 \\
.116 \\
.063 \\
.073 \\
.100 \\
.100 \\
.095\end{array}$ & $\begin{array}{l}.086 \\
.052 \\
.061 \\
.044 \\
.055 \\
.727 \\
.095 \\
.064 \\
.051 \\
.073 \\
.082 \\
.064\end{array}$ & $\begin{array}{l}.073 \\
.064 \\
.057 \\
.064 \\
.058 \\
.278 \\
.189 \\
.061 \\
.084 \\
.114 \\
.064 \\
.064\end{array}$ & $\begin{array}{l}.064 \\
.048 \\
.048 \\
.050 \\
.045 \\
.636 \\
.119 \\
.059 \\
.043 \\
.068 \\
.068 \\
.045\end{array}$ & $\begin{array}{l}.086 \\
.061 \\
.057 \\
.047 \\
.049 \\
.059 \\
.001 \\
.068 \\
.064 \\
.073 \\
.073 \\
.064\end{array}$ & $\begin{array}{l}\cdot 036 \\
.048 \\
.032 \\
.053 \\
\cdot 033 \\
.052 \\
.080 \\
.077 \\
.055 \\
.077 \\
.073 \\
.059\end{array}$ & $\begin{array}{l}\cdot 287 \\
\cdot 118 \\
\cdot 082 \\
\cdot 082 \\
\cdot 075 \\
\cdot 075 \\
\cdot 109 \\
\cdot 105 \\
\cdot 114 \\
\cdot 118 \\
\cdot 145 \\
\cdot 239\end{array}$ & $\begin{array}{l}.082 \\
.073 \\
.061 \\
.051 \\
.059 \\
.061 \\
.077 \\
.073 \\
.075 \\
.077 \\
.095 \\
.100\end{array}$ \\
\hline Nov. $1908-$ Oct. 1909 & $1 \cdot 248$ & $1 \cdot 451$ & $1 \cdot 170$ & $1 \cdot 293$ & $\cdot 792$ & $\cdot 675$ & $1 \cdot 549$ & .884 \\
\hline Average.......... & $\cdot 104$ & $\cdot 121$ & .098 & $\cdot 108$ & .066 & .056 & $\cdot 129$ & .074 \\
\hline 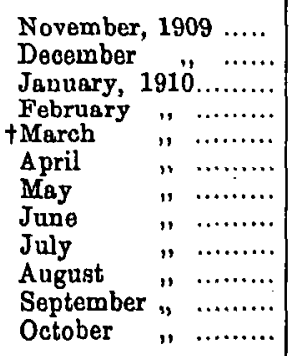 & $\begin{array}{l}.091 \\
.127 \\
.082 \\
.086 \\
218 \\
.142 \\
.090 \\
.073 \\
.086 \\
.091 \\
.100 \\
.089\end{array}$ & $\begin{array}{l}.067 \\
.104 \\
.077 \\
.104 \\
.932 \\
.155 \\
.088 \\
.059 \\
.091 \\
.072 \\
.092 \\
\cdot 141\end{array}$ & $\begin{array}{l}.095 \\
.095 \\
.082 \\
.077 \\
.295 \\
\cdot 145 \\
\cdot 134 \\
\cdot 052 \\
.086 \\
\cdot 102 \\
\cdot 107 \\
\cdot 136\end{array}$ & $\begin{array}{l}.052 \\
.061 \\
.068 \\
-.125 \\
.977 \\
.364 \\
.095 \\
.061 \\
.082 \\
.068 \\
.073 \\
.082\end{array}$ & $\begin{array}{l}.095 \\
.086 \\
.077 \\
.095 \\
.086 \\
.080 \\
.077 \\
052 \\
.068 \\
.083 \\
.080 \\
.068\end{array}$ & $\begin{array}{l}\cdot 068 \\
.058 \\
.064 \\
.082 \\
.061 \\
.061 \\
.086 \\
.118 \\
.086 \\
.089 \\
.068 \\
.039\end{array}$ & $\begin{array}{l}\cdot 114 \\
\cdot 333 \\
\cdot 239 \\
\cdot 173 \\
\cdot 091 \\
\cdot 086 \\
\cdot 082 \\
\cdot 045 \\
.095 \\
\cdot .114 \\
\cdot 214 \\
\cdot 182\end{array}$ & $\begin{array}{l}.082 \\
.079 \\
.073 \\
.095 \\
.059 \\
.064 \\
.045 \\
.041 \\
.173 \\
.117 \\
.096 \\
.095\end{array}$ \\
\hline Nov. 1909-Oct. 1910 & $1 \cdot 275$ & $1 \cdot 982$ & $1 \cdot 406$ & $2 \cdot 108$ & .947 & $\cdot 880$ & $1 \cdot 768$ & $1 \cdot 019$ \\
\hline Average......... & $\cdot 106$ & $\cdot 165$ & $\cdot 117$ & $\cdot 176$ & $.079^{\circ}$ & .073 & $\cdot 147$ & .085 \\
\hline
\end{tabular}

* Manures applied April 7, 1909.

† Manures applied March 16, 1910.

three weeks exposure in the winter being of the same order as those obtained in our prelininary trials with open dishes. Dust however was not absent and may have been a factor in the higher figure for the 
uncovered dish; it is evidently impossible both to exclude dust and permit a quite free play of air. These results render it more probable that the higher results obtained for the upper dishes are due to the increased circulation of air, but before any certainty can be reached it will be necessary to determine whether the air at four feet above the ground does actually contain more ammonia than that down on the surface.

For the same reasons it is hardly possible from these experiments to draw any final conclusion as to whether the soil is an absorber or a source of ammonia. It would be possible to interpret the results on the supposition that the ammonia is added to the air from above, i.e. by chimneys, etc., and that the smaller amount absorbed by the lower dishes is due to the reduction in ammonia in the air close to the soil that has been effected by absorption by soil. The greater amount of ammonia in the air near the laboratory would favour this view.

On the other hand it is difficult to suppose that there can be such a difference in the ammonia content of the air of the two levels, considering the freedom of movement of the open air and the rapidity with which the ammonia can diffuse through it. Again the results show on certain occasions the soil of Broadbalk field is giving off ammonia to such an extent as markedly to enrich the layer of air immediately in contact with the soil, and if the soil is palpably giving off ammonia during the months immediately following the ammoniacal manuring, it must still be doing so at other times of the year, for it has been found that there are always some free ammonium salts in the soil of the Broadbalk field, though the amount sinks to a low and comparatively constant level very shortly after the application of manure.

Pending however the determinations of the distribution of ammonia in the air which are now being undertaken it is impossible to cone to any more definite conclusion as to whether the soil is absorbing or giving off ammonia.

The main object of the investigation has however been attained and it can be concluded with some confidence that whether the soil normally gives off or absorbs ammonia, the total amount of absorption is very small. Even assuming the soil is as effective an absorbing agent as the sulphuric acid in our experiments the maximum absorption per annum amounts to less than a pound per acre, a quantity that would be negligible in any estimates of the gains and losses of nitrogen on a given piece of land under any method of treatment. 